\title{
Inefektifitas Pengaturan Presidential Threshold dalam Undang-Undang Nomor 7 Tahun 2017 tentang Pemilihan Umum
}

\author{
Muhammad Mukhtarrija, I Gusti Ayu Ketut Rachmi Handayani dan Agus Riwanto \\ Fakultas Hukum Universitas Sebelas Maret \\ Jln. Ir. Sutami No. 36A Surakarta \\ mukhtarrija@gmail.com; ayu_igk@yahoo.com; agusriewanto@yahoo.com
}

Received: 26 Juni 2017; Accepted: 7 Februari 2018; Published: 5 Juni 2018

DOI: 10.20885/iustum.vol24.iss4.art7

\begin{abstract}
This study brought up an issue related to the ineffectiveness of the presidential threshold arrangement in Law Number 7 of 2017 on General Election that is correlated with the implementation of simultaneous general election. This was a normative legal study with statute, historical and conceptual approaches. In addition, research sources were needed to solve legal issues and to make recommendations. The sources used in this study included primary and secondary legal materials. The findings showed that the enactment of Law Number 7 of 2017 on General Election is considered ineffective because it has legal issues, such as being contradictory to the amendment of the 1945 Constitution, creating injustice for new political parties that participate in the general election, and weakening the Indonesia's presidential system.
\end{abstract}

Keywords : Ineffectiveness; presidential threshold; general election

Abstrak

Penelitian ini mengangkat permasalahan mengenai inefektifitas pengaturan presidential threshold dalam Undang-Undang Nomor 7 Tahun 2017 tantang Pemilihan Umum yang berkorelasi dengan pelaksanaan pemilihan umum serentak. Jenis penelitian ini adalah penelitian hukum normatif yang menggunakan pendekatan undang-undang, pendekatan sejarah dan pendekatan konseptual. Untuk memecahkan isu hukum dan sekaligus memberi preskripsi mengenai yang seyogyanya, diperlukan sumber-sumber penelitian. Sumber penelitian meliputi bahan hukum primer dan bahan hukum sekunder. Hasil penelitian menyimpulkan bahwa pengesahan Undang-Undang Nomor 7 Tahun 2017 tentang Pemilihan Umum dinilai tidak efektif karena memiliki permasalahan hukum, di antaranya adalah bertentangan dengan amendemen UUD 1945, ketidakadilan partai politik baru peserta pemilihan umum, dan memperlemah sistem presidensial di Indonesia.

Kata-kata Kunci : Inefektifitas; presidential threshold; pemilihan umum 


\section{Pendahuluan}

Teori demokrasi minimalis yang dijelaskan oleh Joseph Shumpeter bahwa pemilihan umum merupakan sebuah arena yang mewadahi kompetisi antara aktor-aktor politik yang meraih kekuasaan partisipasi politik rakyat untuk menentukan pilihan serta liberalisasi hak-hak sipil dan politik warga negara. ${ }^{1}$ Demokrasi merupakan wadah kompetisi untuk untuk meraih kekuasaan dari rakyat melalui proses pemilihan umum. Ukuran demokrasi dalam negara terjadi apabila rakyat dapat berpartisipasi untuk menentukan sikapnya terhadap pemerintahan dan negaranya secara bebas, nyata dan adil.

Menurut Rumi dan Rabi'ah dalam Efriza mengatakan bahwa pemilihan umum sebagai suatu proses di mana pemilih memilih orang-orang untuk mengisi jabatan-jabatan politik tertentu. ${ }^{2}$ Pemilihan umum adalah instrumen yang dapat "direkayasa" untuk melihat corak demokrasi, berjalannya sistem politik dan ketatanegaraan di suatu negara. Karena pemilu akan dapat membawa pengaruh pada tiga hal, yakni, sistem kepartaian, sistem pemerintahan, dan sistem perwakilan. Pendeknya, antara ketiganya adalah satu kesatuan sistem yang tak dapat dipisahkan. ${ }^{3}$

Penulis dapat sarikan, pemilihan umum adalah sarana untuk memilih dan mengisi jabatan-jabataan politik dalam pemerintahan sebagai wakil rakyat yang diselenggarakan secara demokrasi dan adil dengan memiliki kesempatan yang sama bagi setiap kelompok, partai atau golongan tertentu tanpa diskriminasai dan dilaksanakan secara rutin dan berkala diatur berdasarkan konstitusi negara. Melihat pentingnya pemilihan umum dalam negara demokrasi, maka perlu diatur secara khusus dan tegas dalam konsitusi negara tersebut.

Pelaksanaan pemilihan umum di Indonesia berdasarkan Pasal 22E UUD 1945 yang berbunyi: "Pemilihan umum dilaksanakan secara langsung, umum, bebas, rahasia, jujur, dan adil setiap lima tahun sekali." Pengaturan pemilihan umum dalam Amendemen UUD 1945 membuktikan bahwa penting penyelenggaran

\footnotetext{
1 Janpatar Simamora, "Menyongsong Rezim Pemilihan Umum Serentak", artikel dalam Jurnal Rechtsvinding, No. 1 Vol. April 2014, hlm. 2.

${ }^{2}$ Efriza, Political Explore : Sebuah Kajian Ilmu Politik, Alfabeta, Bandung, 2012, hlm. 360.

3 Agus Riwanto, "Inkompatibilitas Asas Pengaturan Sistem Pemilu dengan Sistem Pemerintahan Presidensial di Indonesia” artikel dalam Jurnal Hukum Ius Quia Iustum, No. 4 Vol. 21 Oktober 2014, hlm. 510.
} 
pemilihan umum di Indonesia sebagai pengejewantahan sistem demokrasi. Pemilihan umum di Indonesia bertujuan untuk memilih Presiden dan Wakil Presiden, serta wakil rakyat untuk duduk dalam struktur DPR RI, DPD RI, DPRD Provinsi dan DPRD Kabupaten/Kota.

Pelaksanaan pemilihan umum pasca reformasi tahun 1998 telah mengalami beberapa kali perubahan. Pelaksanaan pemilihan umum pada 1999 berdasarkan Undang-Undang Nomor 3 Tahun 1999 tentang Pemilihan Umum. Pemilihan umum tahun 1999 di Indonesia disebut sebagai demokrasi secara tidak langsung. Hal ini dikarenakan rakyat di dalam proses pemilihan umum hanya memilih DPR RI, sedangkan presiden dan wakil dipilih melalui MPR RI.

Pelaksanaan pemilihan umum 2004 dilaksanakan berdasarkan UndangUndang Nomor 12 Tahun 2003 tentang Pemilihan Umum. Proses pemilihan umum 2004 dilaksanakan secara 2 kali yaitu pemilihan legislatif untuk memilih angggota DPR RI, DPD RI, DPRD Provinsi dan DPRD Kabupaten/Kota dan Pemilihan presiden dan wakil presiden secara langsung oleh rakyat untuk pertama kalinya.

Pemilihan umum yang dilaksanakan pada 2009 dan 2014 tidak memiliki perbedaan yang mencolok dalam pelaksanaannya pada pemilihan umum 2004. Pelakasanaan pemilihan umum 2009 dan 2014 dilaksanakan 2 kali, yaitu untuk pemilihan umum pertama memilih anggota legsilatif DPR RI, DPD RI, DPRD Provinsi dan DPRD Kabupaten/Kota, serta pemilihan yang kedua untuk pemilihan presiden dan wakil presiden. Partai politik atau gabungan partai politik dapat mengusung pasangan calon presiden dan wakil presiden adalah partai politik apabila memiliki perolehan kursi paling sedikit 20\% dari jumlah kursi DPR atau memperoleh $25 \%$ suara sah nasional. Apabila partai politik tidak memenuhi syarat presidential threshold, maka partai politik harus berkoalisi dengan partai peserta pemilihan umum lainnya untuk mengusung calon pasangan presiden dan wakil presiden.

Sebelum pelaksanaan pemilihan umum 2014, Mahkamah Konstitusi Republik Indonesia telah mengeluarkan Putusan Nomor 14/PUU-XI/2013 tentang pelaksanaan pemilihan umum serentak yang akan dilaksanakan pada pemilihan 
umum 2019 dan pemilihan umum seterusnya. ${ }^{4}$ Pemilihan umum serentak yaitu pelaksanaan pemilihan umum legislatif, dan pemilihan umum presiden dan wakil presiden dilaksanakan secara bersamaan. Perlunya pemilihan umum serentak merupakan hasil uji materi (judicial riview) Undang-Undang Nomor 42 Tahun 2008 tentang Pemilihan Presiden terhadap UUD 1945 kepada Mahkamah Konstitusi Republik Indonesia. ${ }^{5}$

Konsep pemiihan umum serentak adalah suatu kebijakkan politik untuk melakukan penggabungan pelaksanaan pemilihan umum legislatif dan pemilihan umum eksekutif dalam satu hari pelaksanaan pemungutan suara. ${ }^{6}$ Secara teori, konsep pemilihan umum serentak berlaku pada negara yang menganut sistem presidensial. Berbeda dengan sistem pemerintahan parlementer, di mana pemilihan umum legislatif dengan sendirinya akan menghasilkan pejabat eksekutif. Sebab partai politik atau koalisi partai politik yang memenangi pemilihan umum yang menguasai mayoritas kursi parlemen sehingga bisa membentuk pemerintahan. ${ }^{7}$

Pemilihan umum serentak merupakan proses pelaksanaan pemilihan umum yang dilaksanakan dalam satu hari pemilihan umum baik pemilihan eksekutif maupun pemilihan legislatif. Pemilihan umum serentak di Indonesia terjadi akibat dari Putusan MK Nomor 14/PUU-XI/2013 yang memutuskan bahwa pemilihan umum tahun 2019 dan seterusnya diselenggarakan secara serentak.

Sejalan dengan amanat putusan Mahkamah Konstitusi Republik Indonesia tersebut, DPR RI mengesahkan Undang-Undang Nomor 7 Tahun 2017 tentang Pemilihan Umum, di mana pemilihan umum tahun 2019 akan diselenggarakan secara serentak. Hal ini sebagaimana tertuang dalam Pasal 167 Angka 1 UndangUndang Nomor 7 Tahun 2017 tentang Pemilihan Umum berbunyi: “Pemilihan umum dilaksanakan setiap 5 tahun sekali."

${ }^{4}$ Lihat Putusan Putusan MK Nomor 14/PUU-XI/2013.

${ }^{5}$ Sodikin, "Pemilihan umum Serentak (Pemilihan umum Legislatif dengan Pemilihan umum Presiden dan Wakil Presiden) dan Penguatan Sietem Presidensial”, artikel dalam Jurnal Rechtsvinding, No. 1 Vol. 3 April 2014, hlm. 20.

${ }^{6}$ Ria Casmi Arrsa, "Pemilu Serentak dan Masa Depan Konsolidasi Demokrasi", artikel dalam Jurnal Konstitusi, No. 3 Vol. 11 September 2014, hlm. 532..

${ }^{7}$ Muhadam Labolo dan Teguh Ilham, Partai Politik dan Sistem Pemiliban Umum Di Indonesia, Rajagrafindo Persada, Jakarta, 2017, hlm. 248. 
Persoalan hukum yang terjadi adalah ketika pelaksanaan pemilihan umum serentak di Indonesia masih mempertahankan ketentuan presidential threshold bagi partai politik untuk mengusungkan pasangan calon presiden dan wakil presiden. Hal ini sebagaimana tertuang dalam Pasal 222 yang berbunyi: "Pasangan Calon diusulkan oleh partai politik atau gabungan partai politik peserta pemilihan umum yang memenuhi persyaratan perolehan kursi paling sedikit 20\% dari jumlah kursi DPR atau memperoleh $25 \%$ dari suara sah secara nasional pada pemilihan umum anggota DPR sebelumnya."

Menurut Harun Husein dalam Sigit Pamungkas mengatakan bahwa pengertian presidential threshold adalah pengaturan tingkat ambang batas dukungan dari DPR, baik dalam bentuk jumlah perolehan suara (ballot) atau jumlah perolehan kursi (seat) yang harus diperoleh partai politik peserta pemilihan umum agar dapat mencalonkan presiden dari partai politik tersebut atau dengan gabungan partai politik. ${ }^{8}$ Presidential threshold adalah syarat ambang batas untuk pengajuan pasangan calon presiden dan wakil presiden oleh partai politik atau gabungan partai politik berdasarkan patokan jumlah suara (ballot) atau jumlah perolehan kursi (seat) pada saat pemilihan legislatif.

Penggunaan presidential threshold dinilai sudah tidak relevan pada pelaksanaan pemilihan umum serentak karena tidak ada patokan yang jelas. Pengaturan presidential threshold berdasarkan hasil pemilihan umum sebelumnya akan menghilangkan kesempatan hak politik partai baru peserta pemilihan umum serentak untuk mencalonkan pasangan calon presiden dan wakil presiden. Hal inilah yang menjadi landasan yang menarik untuk dikaji dan dianalisis tentang inefektifitas pengaturan presidential threshold dalam Undang-Undang Nomor 7 Tahun 2017 tantang Pemilihan Umum.

\section{Rumusan Masalah}

Berdasarkan latar belakang masalah di atas, maka rumusan masalah yang hendak dibahas yaitu: bagaimana inefektifitas pengaturan presidential threshold dalam Undang-Undang Nomor 7 Tahun 2017 tantang Pemilihan Umum?

\footnotetext{
8 Sigit Pamungkas, Peribal Pemilihan umum, Laboratorium Jurusan Ilmu Pemerintahan dan Jurusan Ilmu Pemerintahan Fisipol UGM, Yogyakarta, 2009, hlm. 19.
} 


\section{Tujuan Penelitian}

Penelitian ini memiliki tujuan yaitu, mengkaji dan menganalisis inefektifitas pengaturan presidential threshold dalam Undang-Undang Nomor 7 Tahun 2017 tantang Pemilihan Umum.

\section{Metode Penelitian}

Jenis penelitian ini adalah hukum normatif yang mengkaji isu hukum tentang inefektifitas pengaturan presidential threshold dalam Undang-Undang Nomor 7 Tahun 2017 tentang Pemilihan Umum. Penelitian ini terkonfirmasi dengan pendekatan yang sesuai dan digunakan dalam penelitian hukum ini adalah pendekatan undang-undang (statute approach), pendekatan historis (historical approach), dan pendekatan konseptual (conceptual approach). Pendekatan undangundang (statute approach) dilakukan dengan menelaah semua undang-undang dan regulasi yang bersangkut paut dengan isu hukum yang sedang ditangani. Pendekatan historis (historical approach) dilakukan dengan menelaah latar belakang apa yang dipelajari dan perkembangan pengaturan mengenai isu yang dihadapi. Telaah demikian diperlukan peneliti untuk mengungkap landasan filosofis dan pola pikir yang melahirkan sesuatu yang sedang dipelajari. ${ }^{9}$ Untuk memecahkan isu hukum dan sekaligus memberi preskripsi mengenai yang seyogyanya, diperlukan sumber-sumber penelitian. Sumber penelitian meliputi bahan hukum primer dan bahan hukum sekunder. Bahan hukum primer merupakan bahan hukum yang bersifat autoritatif artinya mempunyai otoritas. Bahan-bahan hukum primer terdiri dari perundang-undangan, catatan-catatan resmi atau risalah dalam pembuatan perundang-undangan dan putusan-putusan hakim. Bahan hukum sekunder berupa semua publikasi tentang hukum yang bukan merupakan dokumen-dokumen resmi, yang meliputi buku-buku teks, dan jurnal-jurnal hukum yang relevan dengan penelitian.10 Bahan hukum primer dan sekunder kemudian dianalisis secara preskriptif analitis.

\footnotetext{
9 Peter Mahmud Marzuki, Penelitian Hukum, Prenadamedia Group, Jakarta, 2014, hlm. 133-136.

${ }^{10}$ Ibid., hlm. 181.
} 


\section{Hasil Penelitian dan Pembahasan}

\section{Inefektifitas Pengaturan Presidential Threshold dalam Undang-Undang Nomor} 7 Tahun 2017 tentang Pemilihan Umum

Pemilihan umum dianggap sebagai lambang sekaligus tolok ukur demokrasi di suatu negara. Syarat mutlak sebagai negara demokrasi adalah dilaksanakannya pemilihan umum untuk menentukan pengisian jabatan politik yang terbuka bagi setiap warga negara sebagai wujud untuk melaksanakan kedaulatan rakyat. Pentingnya pemilihan umum di dalam negara demokrasi tercermin pada pengaturan pemilihan umum secara khusus di dalam konstitusi Negara Indonesia dalam bab tersendiri.

Sistem pemilihan presiden dan wakil presiden di Indonesia sebelum reformasi dilakukan secara tidak langsung dengan suara terbanyak (voting) di MPR RI. MPR RI akan mengadakan pemungutan suara dan calon yang memperoleh suara terbanyak ditetapkan sebagai presiden dan wakil presiden. Hal ini tercantum dalam Pasal 6 Angka 2 UUD 1945 sebelum amendemen berbunyi: "Penentuan Presiden dan Wakil Presiden dengan suara terbanyak (voting) di mana MPR akan mengadakan pemungutan suara dan calon yang memperoleh suarat terbanyak ditetapkan sebagai Presiden dan Wakil Presiden".

Menelisik landasan sejarah amendemen terhadap UUD 1945 menunjukkan bahwa wacana pemilihan presiden dan wakil presiden merupakan topik yang hangat diperdebatkan oleh berbagai kalangan dalam proses amendemen. Perdebatan sebagaimana dimaksud mengemuka sejak Rapat BP MPR ke 2 pada 6 Oktober 1999 terutama mengenai isu seputar apakah pasangan Presiden dan Wakil Presiden tetap dipilih oleh MPR sebagaimana Pasal 6 Angka (2) UUD 1945 ataukah dipilih secara langsung oleh rakyat dalam suatu pemilihan umum. Dalam rapat Lukman Hakim Saifuddin dari F-PPP menyinggung soal perlunya perubahan tata cara Presiden dan Wakil Presiden menjadi lebih terbuka dan demokratis. ${ }^{11}$ Perdebatan terhadap perubahan model pemilihan presiden dan wakil presiden di

11 Sekretariat Jenderal dan Kepaniteraan Mahkamah Konstitusi, Naskah Komprehensif Perubahan UndangUndang Dasar Negara Republik. Indonesia Tabun 1945 (Latar Belakang, Proses, dan Hasil Pembahasan 1999-2002), Mahkamah Konstitusi, Jakarta, 2010, hlm. 240. 
Indonesia menghasilkan keputusan bahwa presiden dan wakil presiden dipilih secara langsung dan demokratis oleh rakyat.

Dasar hukum pemilihan presiden dan wakil presiden secara langsung berdasarkan amendemen UUD Negara Republik Indonesia 1945 yang tercantum dalam Pasal 6A Angka 1 berbunyi: "Presiden dan Wakil Presiden dipilih dalam satu pasangan secara langsung oleh rakyat". Secara konstitusi telah terjadi perubahan kedaulatan rakyat terhadap pemilihan presiden yang sepenuhnya melalui MPR RI menjadi dipilih secara langsung oleh rakyat.

Pemilihan umum yang sebelumnya pada 2004, 2009 dan 2014 dilaksanakan secara 2 kali yaitu pemilihan legsilatif dan pemilihan presiden, mengalami perubahan pasca Putusan Mahkamah Konstitusi Nomor 14/PUU-XI/2013 tertanggal 23 Januari 2014. Putusan yang diajukan oleh Effendi Gazali untuk penyelenggaraan pemilihan umum serentak dikabulkan sebagian oleh Majelis Hakim Mahkamah Konstitusi. Majelis hakim konstitusi membatalkan Pasal 3 Angka (5), Pasal 12 Angka (1) dan (2), Pasal 14 Angka (2) dan Pasal 112 UndangUndang Nomor 42 Tahun 2008 tentang Pemilihan umum Presiden dan Wakil Presiden yang bertentangan dengan konstitusi hasil amendemen UUD 1945.

Mahkamah Konstitusi Republik Indonesia tidak mengabulkan permohonan terhadap pembatalan Pasal 9 Undang-Undang Nomor 42 Tahun 2008 tentang Pemilihan Umum Presiden dan Wakil Presiden. Menurut Mahkamah Konstitusi menyatakan bahwa presidential threshold merupakan kebijakkan pembuat undangundang (opened legal policy). Pendapat ini menjadi rancu apabila disahkan undangundang pemilihan umum dengan model pemilihan umum serentak dan tetap mempertahankan pengaturan presidential threshold.

Secara penafsiran penulis, penyelenggaran pemilihan umum serentak pada tahun 2019 dan seterusnya juga harus membatalkan Pasal 9 Undang-Undang Nomor 42 Tahun 2008 tentang Pemilihan Umum Presiden Dan Wakil Presiden, karena presidential threshold sudah tidak relevan digunakan lagi. Hal ini diungkapkan oleh pakar Hukum Tata Negara, Irman Putra Sidin, mengatakan apabila pemilihan umum serentak, maka tidak ada acuan untuk menentukan 
ambang batas pencalonan presiden karena kursi di DPR belum ada dimiliki oleh partai politik. ${ }^{12}$

Persoalan hukum yang terjadi terhadap penyelenggaran pemilihan umum serentak 2019 dan seterusnya adalah dengan mempertahankan presidential threshold berdasarkan hasil pemilihan umum sebelumnya. Mempertahankan presidential threshold berdasarkan Pasal 222 Undang-Undang Nomor 7 Tahun 2017 tentang Pemilihan Umum memiliki inefektifitas dan justru menimbulkan diskriminasi terhadap partai politik baru peserta pemilihan umum. Berdasarkan analisa penulis, inefektifitas dalam mempertahankan presidential threshold berdasarkan UndangUndang Nomor 7 Tahun 2017 tantang Pemilihan Umum dapat dilihat dari alasan antara lain sebagai berikut:

\section{Bertentangan dengan Amendemen UUD 1945}

Pemilihan umum merupakan suatu konsekuensi dari negara demokrasi. Indonesia sebagai negara demokrasi menjadikan rakyat sebagai pemegang kedaulatan tertinggi dalam menjalankan pemerintahan. Hal ini yang diatur pada Pasal 1 Angka 2 amendemen UUD 1945 berbunyi: "Kedaulatan berada di tangan rakyat dan dilaksanakan menurut Undang-Undang Dasar".

Konsekuensi dari kedaulatan tertinggi di tangan rakyat adalah dilaksanakan pemilihan umum setiap 5 tahun sekali di Indonesia. Pelaksanaan pemilihan umum di Indonesia dianggap merupakan suatu hal yang sangat penting dalam kehidupan ketatanegaraan. Hal ini yang menjadi landasan bahwa proses suksesi kepemimpinan nasional di Indonesia harus diatur secara tegas dalam konstitusi UUD 1945.

Kegiatan pemilihan umum (general election) juga merupakan salah satu sarana penyaluran hak asasi warga negara yang sangat prinsipil. Oleh karena itu, dalam rangka pelaksanaan hak-hak asasi warga negara adalah keharusan bagi pemerintah untuk menjamin terlaksananya penyelenggaraan pemilihan umum sesuai dengan jadwal yang ditentukan. Sesuai dengan prinsip kedaulatan rakyat di mana rakyatlah yang berdaulat, maka semua aspek penyelenggaraan pemilihan

12 Eri Komar Sinaga, "Putusan MK Berdampak Pada Tak Berlakunya Presidential Treshold", http://www.tribunnews.com/pemilu-2014/2014/01/23/putusan-mk-berdampak-pada-tak-berlakunyapresidential-treshold, diakses tanggal 1 November 2017. 
umum itu sendiri pun harus juga dikembalikan kepada rakyat untuk menentukannya. Menjadi sebuah pelanggaran terhadap hak-hak asasi apabila pemerintah tidak menjamin terselenggaranya pemilihan umum, memperlambat penyelenggaraan pemilihan umum tanpa persetujuan para wakil rakyat, ataupun tidak melakukan apa-apa sehingga pemilihan umum tidak terselenggara sebagaimana mestinya. ${ }^{13}$

Proses pelaksanaan pemilihan umum harus dilaksanakan secara adil dengan memberi kesempatan sama yang bagi rakyat, kolompok dan partai tertentu dan tidak bertentangan dengan ketentuan-ketentuan konstitusi sebagai aturan tertinggi dalam suatu negara. Aturan lebih lanjut mengenai pemilihan umum akan diatur di dalam peraturan perundang-undangan sebagai dasar hukum pelaksana pemilihan umum secara rinci, sebagaimana yang diatur dalam Pasal 22E Angka 6 Amendemen UUD 1945 berbunyi: "Ketentuan lebih lanjut tentang pemilihan umum diatur dengan undang-undang".

Berdasarkan ketentuan tersebut, DPR RI sebagai lembaga legislasi nasional dapat membuat undang-undang pemilihan umum sebagai dasar hukum pelaksanaan pemilihan umum di Indonesia. Dalam membuat aturan perundanganundangan tentang pemilihan umum tersebut, harus memerhatikan prinsip-prinsip keadilan dan tidak bertentangan dengan UUD 1945.

Berlakunya Undang-Undang Nomor 7 Tahun 2017 tentang Pemilihan Umum telah bertentangan dengan UUD 1945. Secara yuridis undang-undang tersebut tidak dapat dijalankan karena bertentangan dengan aturan yang lebih tinggi. Adapun ketentuan Undang-Undang Nomor 7 Tahun 2017 tentang Pemilihan Umum yang bertentangan dengan amendemen UUD 1945 adalah terdapat pada Pasal 6A Angka 2 UUD 1945 yang berbunyi: "Pasangan calon Presiden dan Wakil Presiden diusulkan oleh partai politik atau gabungan partai politik peserta pemilihan umum sebelum pelaksanaan pemilihan umum."

Pasal 6A Angka 2 Amendemen UUD 1945 tersebut, memberi penjelasan bahwa setiap partai politik peserta pemilihan umum memiliki hak dan kesempatan yang sama untuk mencalonkan pasangan presiden dan wakil presiden. Berlakunya

${ }^{13}$ Jimmly Asshiddiqie, Perihal Undang-Undang, Rajawali Pers, Jakarta, 2011, hlm. 1. 
Undang-Undang Nomor 7 Tahun 2017 tentang Pemilihan Umum telah menghilangkan hak partai politik peserta pemilihan umum serentak terutama partai politik baru peserta pemilihan umum 2019 dan seterusnya dikarenakan ketentuan dari Pasal 222. Secara logika hukum, partai politik baru peserta pemilihan umum serentak akan tersendera dengan ketentuan presidential threshold tersebut. Hal ini yang menjadi pertimbangan pertentangan Pasal 222 UndangUndang Nomor 7 Tahun 2017 tentang Pemilihan Umum terhadap Pasal 6A Angka 2 Amendemen UUD 1945.

\section{Ketidakadilan Partai Politik Baru Peserta Pemilihan Umum}

Menurut Laurence Whitehead dalam Ria Casmi Arrsa mengatakan konsolidasi demokrasi tidak hanya merupakan proses politik yang terjadi pada level prosedural lembaga-lembaga politik tetapi juga pada level masyarakat. Demokrasi akan terkonsolidasi bila aktor-aktor politik, ekonomi, negara, masyarakat sipil (political society, economic society, the state dan civil society) mengedepankan tindakan demokratis sebagai alternatif utama untuk meraih kekuasaan. ${ }^{14}$

Pemilihan umum yang merupakan alternatif utama untuk meraih kekuasaan harus mengacu pada aturan main (rule of the game) yang tentukan oleh undangundang. Peraturan perundang-undangan pemilihan umum sebagai aturan main (rule of the game) mengikuti mekanisme keadilan dan persamaan kesempatan bagi semua pihak. Hal ini memberi penjelasan bahwa aturan main (rule of the game) dalam pemilihan umum yang tidak mengutamakan prinsip keadilan dan persamaan kesempatan, maka dapat dikatakan cacat secara demokrasi.

Mengutip salah satu prinsip hukum dan keadilan yang dianut secara universal menyatakan bahwa "tidak seorang pun boleh diuntungkan oleh penyimpangan dan pelanggaran yang dilakukannya sendiri dan tidak seorang pun boleh dirugikan oleh penyimpangan dan pelanggaran yang dilakukan oleh orang lain" (nullus/nemo commodum capere potest de injuria sua propria). ${ }^{15}$ Negara tidak dibenarkan dalam menyusun peraturan perundangan-undangan yang terdapat

${ }^{14}$ Ria Casmi Arrsa, Op. Cit., hlm. 526.

15 Indra Perwira, "Refleksi Fenomena Judicialization of Politics pada Politik Hukum Pembentukan Mahkamah Konstitusi dan Putusan Mahkamah Konstitusi”, artikel dalam Jurnal Konstitusi, No. 1 Vol. 13 Maret 2016, hlm. 43. 
penyimpangan dan pelanggaran terhadap hak-hak politik kelompok tertentu dan menguntungkan kelompok yang lain.

Kebijakkan-kebijakkan hukum yang memiliki konsep ketidakadilan harus dikoreksi kembali dan diubah agar sesuai dengan prinsip keadilan yang sama dan tanpa mendiskriminasi masyarakat, partai politik golongan tertentu. Melihat alasan tersebut, dapat disimpulkan bahwa setiap negara yang ingin mengeluarkan suatu kebijakkan hukum baik berupa peraturan perundang-undangan dan kebijakkan yang dikeluarkan oleh pemerintahan harus mempertimbangkan secara matang apakah aturan tersebut melanggar hak-hak sipil masyarakat, partai politik golongan tertentu atau tidak.

Berlakunya Undang-Undang Nomor 7 Tahun 2017 tentang Pemilihan Umum memiliki dampak ketidakadilan terhadap partai politik baru sebagai peserta pemilihan umum serentak. Berlakunya Undang-Undang Nomor 7 Tahun 2017 tentang Pemilihan Umum tidak berprinsip dengan aturan main (rule of the game) dari pemilihan umum yang adil. Hal ini tercermin kepada Pasal 222 yang berbunyi:

Pasangan Calon diusulkan oleh Partai Politik atau Gabungan Partai Politik Peserta Pemilu yang memenuhi persyaratan perolehan kursi paling sedikit 20\% (dua puluh persen) dari jumlah kursi DPR atau memperoleh 25\% (dua puluh lima persen) dari suara sah secara nasional pada Pemilu anggota DPR sebelumnya.

Pasal 222 tersebut secara sepihak telah menguntungkan partai politik yang pada pemilihan umum 2014 yang memiliki kursi di DPR. Padahal pada pemilihan umum tahun serentak juga terdapat partai baru yang secara konstitusi memiliki kesempatan yang sama untuk mencalonkan pasangan presiden dan wakil presiden. Hal ini berdasarkan ketentuan Pasal 6A Angka 2 berbunyi : "Pasangan calon Presiden dan Wakil Presiden diusulkan oleh partai politik atau gabungan partai politik peserta pemilihan umum sebelum pelaksanaan pemilihan umum".

Demokrasi pada dasarnya memiliki potensi untuk memberikan suatu yang baik bagi manusia terutama dalam menghadapi kekuasaan yang represif dan rakyat dipandang memiliki kesetaraan dalam politik (politcal equity). ${ }^{16}$ Kesetaraan

${ }^{16}$ Anwar Arifin, Komunikasi Politik (Filsafat-Paradigma-Teori-Tujuan Strategi dan Komunikasi Politik Di Indonesia, Graha Ilmu, Yogyakarta, 2011, hlm. 43. 
dalam politik (politcal equity) dapat diperoleh melalui persamaan hak dan kesempatan setiap masyarakat, kelompok atau partai politik dalam proses pemilihan umum.

Kesetaraan dalam politik (politcal equity) merupakan prinsip utama dari negara demokrasi melaui perlakuan yang sama tanpa diskriminasi baik rakyat, kelompok maupun partai politik tertentu. Hak dan kesempatan dari partai politik baru peserta pemilihan umum serentak untuk mencalonkan pasangan presiden dan wakil presiden tidak dapat dihilangkan oleh aturan undang-undang yang tidak adil (unfair).

Tujuan pemberian kesempatan yang sama kepada para peserta pemilihan umum untuk memenangkan pemilihan umum, yang juga berarti para peserta pemilihan umum mempunyai peluang yang sama untuk memenangkan programprogramnya. Negara-negara demokrasi, pergantian pejabat pemerintahan eksekutif dan legislatif ditentukan secara langsung oleh rakyat, yaitu melalui pemilihan umum (general election) yang diselenggarakan secara periodik. ${ }^{17}$

Menurut Amartya Sen dalam anwar Arifin meyakini bahwa demokrasi dapat berkembang dengan baik jika mampu menipis ketidakadilan dan mempercepat pembangunan ekonomi. ${ }^{18}$ Menurut Merloe dalam Harry Setya Nugraha yang menggolongkan pemilihan umum demokratis haruslah mencakup 3 hal penting, yaitu: 1) ada tidaknya pengakuan, perlindungan, dan pemupukan Hak Asasi Manusia (HAM); 2) terdapat persaingan yang adil dari peserta pemilihan umum; 3) terbangunnya kepercayaan masyarakat terhadap pemilihan umum yang menghasilkan pemerintahan yang legitimate. ${ }^{19}$

Menurut John Rawls dalam Dessy Artina mengatakan bawah keadilan menuntut pentingnya distribusi yang sifatnya adil atas semua kesempatan, peranan, kedudukan, serta manfaat-manfaat atau nilai-nilai sosial asasi yang terdapat di dalam masyarakat. ${ }^{20}$ Negara tidak dapat disebut sebagai negara

${ }^{17}$ Jimly Asshiddiqie, Pengantar Ilmu Hukum Tata Negara Jilid II, Konstitusi Press, Jakarta, 2006, hlm. 176.

18 Anwar Arifin, Op. Cit., hlm. 43.

19 Harry Setya Nugraha, "Redesain Kewenangan Mahkamah Konstitusi dalam Penyelesaian Sengketa Perselisihan Hasil Pemilihan Umum Presiden dan Wakil Presiden di Indonesia”, artikel dalam Jurnal Hukum Ius Quia Iustum, No. 3 Vol. 22 Juli 2015, hlm. 427.

${ }^{20}$ Dessy Artina, "Keterwakilan Politik Perempuan dalam Pemilu Legislatif Provinsi Riau Periode 20142019”, artikel dalam Jurnal Hukum Ius Quia Iustum, No. 3 Vol. 23 Januari 2015, hlm. 129. 
demokrasi apabila masih terdapat ketidakadilan dalam meraih kekuasaan politik melalui pemilihan umum yang diselenggarakan secara berkala dan periodik.

Prinsip keadilan yang setara adalah ketika diterapkan prosedur politik yang ditetapkan oleh konstitusi akan memiliki prinsip (kesetaraan) partispasi. Prinsip ini menyatakan bahwa semua warga negara mempunyai hak yang setara untuk ambil bagian, dan untuk menentukan hasil dari proses konstitusional. ${ }^{21}$ Presiden terpilih sebagai hasil dari pemilihan umum harus melalui tahap konstitusi yang sah dan berkeadilan tanpa menguntungkan atau merugikan pihak masyarakat, golongan dan partai politik tertentu.

Jadi berdasarkan ulasan tersebut dapat dinyatakan bahwa berapapun jumlah presidential threshold terhadap pelaksanaan pemilihan umum serentak berdasarkan hasil pemiliha umum sebelumnya, maka tetap dianggap inkonstitusinal karena mengabaikan hak politik partai baru peserta pemilihan umum. Berlakuya UndangUndang Nomor 7 Tahun 2017 tentang Pemilihan Umum harus ditinjau ulang kembali dengan menghapus ketentuan Pasal 222, agar tercipta penyelenggaran pemilihan umum yang adil dan memiliki kesempatan yang sama sabagai aturan main (rule of the game).

\section{Memperlemah Sistem Presidensial di Indonesia}

Penguatan terhadap sistem presidensial sebagaimana disepakati oleh MPR RI diawal proses perubahan UUD 1945 akan berpengaruh terhadap tata cara pemilihan Presiden dan Wakil Presiden, bahwa dalam pelaksanaan sistem presidensial, Presiden bertanggung jawab kepada rakyat secara langsung dan bukan melalui MPR. ${ }^{22}$ Melalui kesepakatan sistem pemerintahan presidensial berdasarkan Amendemen UUD 1945, maka sistem pemilihan umum di Indonesia berubah menjadi demokrasi secara langsung terhadap pemilihan presiden dan wakil presiden.

${ }^{21}$ John Rawls, Teori Keadian: Dasar-Dasar Filsafat Politik. untuk. Mewujdudkan Kesejabteraan Sosial dalam Negara, Alih Bahasa, Uzair Fauzan dan Heru Prasetyo, Pustaka Pelajar, Yogyakarta, 2011, hlm. 280.

22 Jimly Asshiddiqie, Konstitusi dan Konstitusionalisme Indonesia, Sinar Grafika, Jakarta, 2010, hlm. 62-63 dan 168-169. 
Moh. Mahfud MD, mengatakan bahwa prinsip pokok sistem presidensial adalah $^{23}$ :

a. Kepala negara menjadi kepala pemerintahan (eksekutif);

b. Pemerintah tidak bertanggungjawab kepada parlemen (DPR). Pemerintah dan Parlemen adalah sejajar;

c. Menteri-menteri diangkat dan bertanggungjawab kepada presiden;

d. Eksekutif dan legislatif sama-sama kuat.

Menurut Saldi Isra juga mengatakan baahwa sistem pemerintahan presidensial memiliki karakter yang utama dan beberapa karakter lainnya yakni24:

a. Presiden memegang fungsi ganda, sebagai kepala negara dan sekaligus kepala pemerintahan. Meskipun sulit untuk dibedakan secara jelas, presiden sebagai kepala negara dapat dikatakan sebagai simbol negara, sebagai kepala pemerintahan, presiden merupakan pemegang kekuasaan tunggal dan tertinggi.

b. Presiden tidak hanya sekedar memilih anggota kabinet, tetapi juga berperan penting dalam pengambilan keputusan di dalam kabinet.

c. Hubungan antara eksekutif dan legislatif terpisah, dengan adanya pemilihan umum untuk memilih presiden dan memilih lembaga legislatif;

d. Dengan pemisahan secara jelas antara pemegang kekuasaan legislatif dan eksekutif, pembentukan pemerintahtidak tergantung kepada prosespolitik di lembaga legislatif

e. Sistem pemerintahan presidensial dibangun dalam prinsip clear cut separation of powers antara pemegang kekuasaan legislatif dan kekuasaan eksekutif dengan konsekuensi bahwa antara legislatif dan eksekutif tidak mempunyai hubungan kerjasama. Artinya terjadi pemisahan secara tegas antara presiden dengan legislatif.

Berdasarkan pendapat tersebut dapat ditarik benang merah bahwa sistem presidensial adalah sistem pemerintahan di mana presiden sebagai kepala negara dan kepala pemerintahan dalam menjalankan tugas dan fungsinya bertanggungjawab kepada rakyat sebagai pemilih. Presiden yang menjalankan tugas dan fungsinya hanya bertanggungjawab terhadap rakyat, apabila diterima oleh rakyat tentu akan terpilih kembali menjadi presiden untuk satu periode berikutnya melalui pemilihan umum.

${ }^{23}$ Moh. Mahfud MD, Dasar dan Struktur Ketatanegaraan Indonesia, Rineka Cipta, Jakarta, 2001, hlm. 74.

${ }^{24}$ Saldi Isra, Pergesaran Fungsi Legislasi, Menguatnya Model Legislasi Parlementer Dalam Sistem Presidensial di Indonesia, Raja Grapindo, Jakarta, 2010, hlm. 40-42. 
Pemilihan umum serentak (concurrent elections) bertujuan memperbaiki sistem sistem pemerintahan presidensial. ${ }^{25}$ Ketidakharmonisan sistem presidensial dengan sistem multipartai di parlemen, adalah karena adanya keterpisahan secara tugas (separation of power) antara presiden dan parlemen dengan ditandai adanya pemilihan presiden dan pemilihan legislatif yang berbeda, sehingga berpotensi melahirkan jenis dukungan partai yang berbeda, sekaligus tidak paralel antara partai yang menguasai parlemen dan partai yang memenangkan pemilihan. ${ }^{26}$

Pemilihan umum serentak (concurrent elections) didefinisikan sebagai sistem pemilihan umum yang menyelenggarakan pemilihan umum baik DPR RI, DPD RI Presiden dan Wakil Presiden, DPRD Provinsi dan DPRD Kabupaten/Kota dilaksanakan dalam satu waktu secara bersamaan. Manfaat dari pelaksanaan pemilihan umum serentak adalah memperkuat sistem presidensial di Indonesia. Sistem presidensial yang efektif terjadi apabila pemerintahan didukung oleh partai mayoritas pendukung pemerintah.

Menurut Mahkamah Konstitusi, pelaksanaan pemilihan umum presiden setelah pemilihan umum legislatif tidak juga memperkuat sistem presidensial yang hendak dibangun berdasarkan konstitusi. Pasangan calon presiden dan wakil presiden kerap menciptakan koalisi taktis yang bersifat sesaat dengan partai-partai politik sehingga tidak melahirkan koalisi jangka panjang yang dapat melahirkan penyederhanaan partai politik secara alamiah. ${ }^{27}$ Koalisi yang terjadi pada pemilihan presiden setelah pemilihan legislatif cenderung kepada arah politik kepentingan dari partai politik pendukung seperti pembagian jabatan politik di struktur kabinet pemerintahan yang akan dibentuk.

Penghapusan presidential threshold pada pemilihan umum serentak bertujuan untuk memanfaatkan teori coattail effect. Teori coattail effect, yakni setelah memilih calon presiden dan wakil presiden, pemilih cenderung memilih partai politik atau koalisi partai politik yang mencalonkan presiden yang dipilihnya. 28 Partai politik

25 Usep Hasan Sadikin, "Paradaoks Pemilu Serentak Indonesia", http://www.rumahpemilihan umum.org/id/paradoks-pemilihan umum-serentak-indonesia/, diakses tanggal 28 Oktober 2017.

26 Agus Riwanto, Op. Cit., hlm. 518.

${ }^{27}$ Lihat Putusan Mahkamah Konstitusi Republik Indonesia Nomor 14/PUU-XI/2013 hlm. 81.

${ }^{28}$ Ibid., hlm. 8 
yang mengusungkan pasangan calon presiden dan wakil presiden yang disukai rakyat, maka rakyat tersebut secara otomatis juga akan memilih partai politik calon pasangan presiden dan wakil presiden tersebut.

Pernyataan Shugart tentang teori coattail effect, yang akan diperoleh jika pemilihan umum dilaksanakan serentak. Contoh Pemilihan umum serentak mulai diterapkan di Brasil sejak awal 1994 dan berhasil menstabilkan dan mengefektifkan pemerintahan, sehingga dalam kurun 15 tahun kemudian, Brasil menjadi kekuatan ekonomi dunia. ${ }^{29}$ Memanfaatkan teori coattail effect pada pemilihan umum serentak dapat terjadi dengan tidak adanya pengaturan presidential threshold. Presiden terpilih melalui sistem pemilihan umum serentak tanpa presidential threshold, memiliki kekuatan politik yang kuat dan tidak tersendara oleh mahar politik koalisi partai pendukung.

Partai politik peserta pemilihan umum lebih menawarkan ideologi partai dan mempersiapkan sedini mungkin pasangan calon presiden dan wakil presiden yang disukai oleh rakyat. Kecenderungan rakyat yang memilih calon pasangan presiden dan wakil presiden dan partai yang sama akan menciptakan sistem pemerintahan presidensial yang kuat. Partai politik dari calon presiden dan wakil presiden terpilih akan menjadi partai pemenang pemilihan umum di legislatif sehingga jalannya pemerintahan yang dibentuk akan stabil.

\section{Penutup}

Berdasarkan uraian di atas, maka dapat diambil kesimpulan bahwa pengaturan presidential threshold berdasarkan Undang-Undang Nomor 7 Tahun 2017 tentang Pemilihan Umum memiliki infektifitas pada pelaksanaanya dalam pemilihan umum serentak. Inefektifitas tersebut dikarenakan yakni: (1) bertentangan dengan Amendemen UUD 1945 (2) ketidakadilan partai politik baru peserta pemilihan umum (3) memperlemah sistem presidensial di Indonesia.

Berdasarkan hasil kesimpulan, maka perlu dilakukan penghapusan terhadap Pasal 222 Undang-Undang Nomor 7 Tahun 2017 agar pelaksanaan sesuai dengan prinsip negara demokrasi. Penguatan ideologi dan sistem kader partai politik menjadi hal yang penting pada saat penyeleksian partai politik peserta pemilihan

${ }^{29}$ Ibid., hlm. 9 
umum, sehingga terjadinya partai politik peserta pemilihan umum kedepannya benar-benar partai yang kuat secara ideologi dan memiliki basis massa yang besar.

\section{Daftar Pustaka}

\section{Buku}

Arifin, Anwar, Komunikasi Politik (Filsafat-Paradigma-Teori-Tujuan Strategi dan Komunikasi Politik Di Indonesia, Graha Ilmu, Yogyakarta, 2011.

Asshiddiqie, Jimly, Pengantar Ilmu Hukum Tata Negara, Jilid II, Konstitusi Press, Jakarta, 2006.

__, Konstitusi dan Konstitusionalisme Indonesia, Sinar Grafika, Jakarta, 2010. , Perihal Undang-Undang, Rajawali Pers, Jakarta 2011.

Efriza, Political Explore : Sebuah Kajian Ilmu Politik, Alfabeta, Bandung, 2012.

Isra, Saldi, Pergesaran Fungsi Legislasi, Menguatnya Model Legislasi Parlementer Dalam Sistem Presidensial di Indonesia, RajaGrapindo, Jakarta, 2010.

Labolo, Muhadam dan Teguh Ilham, Partai Politik Dan Sistem Pemilihan Umum Di Indonesia, Rajagrafindo Persada, Jakarta, 2017.

Mahfud MD, Moh., Dasar dan Struktur Ketatanegaraan Indonesia, Rineka Cipta,Jakarta 2001.

Mahmud Marzuki, Peter, Penelitian Hukum, Prenadamedia Group, Jakarta, 2014.

Pamungkas, Sigit, Perihal Pemilihan umum, Laboratorium Jurusan Ilmu Pemerintahan dan Jurusan Ilmu Pemerintahan Fisipol UGM, Yogyakarta, 2009.

Rawl, John, Teori Keadian: Dasar-Dasar Filsafat Politik untuk Mewujdudkan Kesejahteraan Sosial dalam Negara, Alih Bahasa, Uzair Fauzan dan Heru Prasetyo, Pustaka Pelajar, Yogyakarta, 2011.

Sekretariat Jenderal dan Kepaniteraan Mahkamah Konstitusi, Naskah Komprehensif Perubahan Undang- Undang Dasar Negara Republik Indonesia Tahun 1945 (Latar Belakang, Proses, dan Hasil Pembahasan 1999-2002), Mahkamah Konstitusi, Jakarta, 2010.

\section{Jurnal}

Artina, Dessy, "Keterwakilan Politik Perempuan dalam Pemilu Legislatif Provinsi Riau Periode 2014-2019", Jurnal Hukum Ius Quia Iustum, No. 3 Vol. 23 Januari 2015.

Casmi Arrsa, Ria, "Pemilu Serentak dan Masa Depan Konsolidasi Demokrasi", Jurnal Konstitusi, No. 3 Vol. 11 September 2014.

Perwira, Indra, "Refleksi Fenomena Judicialization of Politics pada Politik Hukum Pembentukan Mahkamah Konstitusi dan Putusan Mahkamah Konstitusi", Jurnal Konstitusi, No. 1 Vol. 13 Maret 2016 
Riwanto, Agus, "Inkompatibilitas Asas Pengaturan Sistem Pemilu dengan Sistem Pemerintahan Presidensial di Indonesia" Jurnal Hukum Ius Quia Iustum, No. 4 Vol. 21 Oktober 2014.

Setya Nugraha, Harry, "Redesain Kewenangan Mahkamah Konstitusi dalam Penyelesaian Sengketa Perselisihan Hasil Pemilihan Umum Presiden dan Wakil Presiden di Indonesia", Jurnal Hukum Ius Quia Iustum, No. 3 Vol. 22 Juli 2015.

Simamora, Janpatar, "Menyongsong Rezim Pemilihan umum Serentak", Jurnal Rechtsvinding, No. 1 Vol. 3 April 2014.

Sodikin, "Pemilihan Umum Serentak (Pemilihan Umum Legislatif dengan Pemilihan Umum Presiden dan Wakil Presiden) dan Penguatan Sietem Presidensial", Jurnal Rechtsvinding, No. 1 Vol. 3 April 2014.

\section{Internet}

Hasan Sadikin, Usep, "Paradaoks Pemilu Serentak Indonesia", http://www.rumahpemilihan umum.org/id/paradoks-pemilihan umumserentak-indonesia/ diakses tanggal 28 Oktober 2017.

Komar Sinaga, Eri, “Putusan MK Berdampak Pada Tak Berlakunya Presidential Treshold", http://www.tribunnews.com/pemilu-2014/2014/01/23/ putusan-mk-berdampak-pada-tak-berlakunya-presidential-treshold diakses tanggal 1 November 2017. 